\title{
GENETIC VARIABILITY OF POLYMESODA EROSA POPULATION IN THE SEGARA ANAKAN CILACAP
}

\author{
AGUS NURYANTO* AND AGUS HERY SUSANTO \\ Faculty of Biology, Jenderal Soedirman University, Purwokerto, Indonesia
}

\begin{abstract}
Mud clams, Polymesoda erosa, in the Segara Anakan Cilacap are highly exploited by the local communities for daily consumption. This is presumed causing population decline and potentially causing loss of genetic diversity. Genetic diversity level within population can be obtained by population genetic study using molecular marker such as randomly amplified polymorphic DNA (RAPD). Here we amplified RAPD marker using ten arbitrary primers to assess genetic diversity of P. erosa population in the Segara Anakan Cilacap to provide genetic data for its sustainable use. The results proved that the use of RAPD marker has high polymorphisms. The mud clam population also showed a high level of heterozygosity and genetic diversity. This has important implication for the management plan towards sustainable use of P. erosa in the Segara Anakan Cilacap.
\end{abstract}

Keywords: mud clam, RAPD, polymorphism, genetic diversity.

\section{INTRODUCTION}

Mud clams, also known as mangrove clams of the genus Polymesoda, are widely distributed in the mangrove habitat. Three species of mangrove clams belonging to the genus Polymesoda are reported from the Indo-Pacific regions (Ingole et al. 2002). They are Polymesoda erosa, P. bengalensis and P. expansa. P. erosa is distributed almost in all Indo-Pacific coastal regions, including in the Segara Anakan Cilacap, Central Java, Indonesia.

Mangrove clams, P. erosa, have considerably big size with more flesh body. Adult individuals of P. erosa might reach $11 \mathrm{~cm}$ in shell size (Gimin et al. 2004). Therefore, it is not surprising that these clams are utilized as one of food resources by local community who lives close to the coastal region (Meehan 1982) including the community near the Segara Anakan areas, Cilacap (Dudley et al. 2000). Moreover, this mangrove clam has a good quality to be reared in mariculture (Morton 1976).

In the Segara Anakan areas, P. erosa are collected by the fishermen to fulfill their daily consumption (livelihood) or even for sale at local market in Cilacap and surrounding areas. This is indicating that mud clams, P. Erosa, in the Segara Anakan is

*Corresponding author: aghnia_unsoed@yahoo.com 
highly exploited. On the other hand, the size of Segara Anakan areas has been reduced due to land conversion, sedimentation, and so on (Hanley 2000). Formerly, Segara Anakan had around 4603 ha of mangrove areas. However, illegal logging had caused the area of mangrove forest became smaller and smaller; it was around 1454 ha between 1974 and 1987. In 1989, about 16.5 ha of mangrove forest in the Segara Anakan areas had been converted into shrimp ponds. The decrease of mangrove area in the Segara Anakan is also caused by sedimentation which is coming from Citanduy, Cibeureum, and Cikonde Rivers (Sastranegara 2004).

A high rate of exploitation and declining of the Segara Anakan areas are presumed to have direct impact on its animal communities, including P. erosa population. The alteration of natural communities could be reflected by the changes of biodiversity and abundances (Kempton 1979), especially on the benthic organisms (Lambshead et al. 1983). Biodiversity is divided into three levels: (1) intraspecific diversity, it is well known as genetic diversity within population, (2) species diversity and (3) ecosystem diversity (Fe' ral 2002). Hauser et al. (2002) noted that overexploitation may cause a loss or decrease of genetic diversity within population which potentially affects adaptation capability, population resistance and productivity.

Genetic diversity level within population can be obtained by population genetic study using molecular marker such as randomly amplified polymorphic DNA (RAPD). A study on population genetic is intended to evaluate genetic variation of the population under study. Genetic variation level within a population is one of the vital information that supports conservation effort (Lande \& Barrowclough 1998, Simberloff 1988, Suryadi 2002). This is due to genetic diversity which is needed by the species to maintain their reproductive capability and adaptation to their environmental alteration (O'Brien 1994, Fe'ral 2002, Reed \& Frankham 2003) including their resistance to several types of diseases (Tarpy 2003, Hughes \& Stachowicz 2004). In other words, species need to be variable enough in their genetic resources to be adaptive to their environment. Moreover, information on genetic diversity data is very important to support the utilization of nature resources. Indriani et al. (2002) noted that higher variation will lead to a higher probability to obtain organism with the expected character. Information about species abundance and diversity are very important for the sustainable use of natural communities in a given ecosystem. According to Hadie et al (1998), restoration and conservation effort should consider local populations; firstly, because it is related to local adapted gene, the second consideration is to introduce other genes from metapopulation with better intraspecific genetic variation. This agrees with Savolainen (1994) that genetic variation is an important component of genetic diversity conservation, because it is directly related with adaptation.

A study on genetic diversity can be done using DNA and proteomics. Both markers are relatively stable or not greatly affected by the environment (Purwanto et al. 2002). However, DNA marker provides more advantages compared with proteomics markers. The advantage of DNA as genetic marker is that it provides direct information on variation within a given population (Ward \& Grew 1994).

Several DNA markers have been developed to study genetic diversity of population. They are DNA sequences (nuclear DNA and mitochondrial DNA), 
RFLP, AFLP, RAPD and so on (Fe'ral 2002). Random amplified polymorphic DNA (RAPD) analysis is an analysis using arbitrary oligonucleotide with 10 bases length as a primer to amplify DNA fragment from discrete genome. RAPD analysis provides a cheaper and faster technique compared with restriction fragment-length polymorphism (RFLP) analysis (Penner et al. 1993). Moreover, this method also provides an alternative method to identify DNA polymorphisms related to commercial characters.

RAPD technique results to a huge number of DNA fragment the majority of which are individual specific (Welsh \& McClelland 1990, Williams et al. 1990). If heritability pattern is verified, RAPD patterns can also be used for population genetic analysis (Williams et al. 1990) that includes intraspecific genetic variation analysis. However, there is a possibility that dominancy occurred on RAPD marker. If this is the case, genetic variation may be hidden and small fragments are not visualized. In order to avoid this case, during the research primers were used which produced consistent RAPD marker and showed polymorphism on bivalve specimen following Rego et al. (2002) and Holmes et al. (2004). The potential of RAPD marker used on population genetic analysis had been reported on several organisms (Hadrys et al. 1992). This technique has proven the presence of genetic polymorphism on intraspecific level, such as on oyster (Hirschfeld et al. 1999, Klinbunga et al. 200\%, Klinbunga et al. 2001), mussels (Rego et al. 2002), scallop (Patwary et al. 1994), ab2lone (Huang et al. 2000), zebra and quangga mussels (Stepien et al. 2002), and bivahe Abra tenuis (Holmes et al. 2004). Baozhong et al. (2006) proved that RAPD marker provide more information about genetic diversity within population compared/with enzymes electrophoresis, especially on scallop (Chlamys farreri). Moreover, RAP marker can also be used in species identification (Rego et al. 2002, Marin et al. 2007).

This study is aimed to obtain information on RAPD marker with consistent and polymorphic band and genetic diversity data on P. erosa population in the Segara Anakan Cilacap. The obtained data is valuable to evaluate the genetic potential of $P$. erosa resources in the Segara Anakan Cilacap, so it can be used as a basis to create a strategy of sustainable use of the clam resources.

\section{MATERIALS AND METHODS}

\section{Sample collection}

Mantle tissues of P. erosa were collected from the Segara Anakan Cilacap during the field trips in 2009. DNA analysis was carried out at the Plant Biology Laboratory, Research Centre for Life Sciences and Biotechnology, Bogor Agriculture University. A small piece of mantel tissues were cut off from each specimen with the help of forceps and scissors. Mantle Tissue samples were preserved on $96 \%$ of ethanol and stored at $4^{\circ} \mathrm{C}$ until DNA analysis.

\section{DNA isolation and RAPD Amplification}

Total genomic DNA was isolated using Chelex ${ }^{\circledR}$ method from 20 individuals and following the protocols from Walsh et al. (1991) with slight modification as follows: 
approximately $2 \times 2 \times 0.3 \mathrm{~mm}^{3}$ muscle tissue was cut off and put in Eppendorf tubes of $1.5 \mathrm{ml}$. Add $100 \mu \mathrm{l}$ Chelex 5\%, $5 \mu \mathrm{l}$ Dithiotreitol $100 \mathrm{mM}$ and $4 \mu \mathrm{l}$ Proteinase-K into the tubes. The samples were incubated for four hours at $55{ }^{\circ} \mathrm{C}$. Afterwards, the samples were centrifuged at $13.000 \mathrm{rpm}$ for 3 minutes. The supernatants were transferred into new tubes and finally incubated at $95^{\circ} \mathrm{C}$ for 5 minutes. The RAPD markers were amplified using the following ten primers: GEN11 TGCGCGATCG, GEN12 CAGGGTCGAC, GEN13 ACGGTGCCTG, GEN14 CGCATTCCGC, GEN15 GAGATCCGCG, GEN16 GGACTCCACG, GEN17 ATCTCCCGGG, GEN20 CAGACACGGC, and GEN23 GTGTAGGGCG, GEN24 CGGGTCGATC (Aranisi \& Okimoto 2004).

PCR reactions were carried out in a total volume of $25 \mu$ l containing approximately $0.15 \mu \mathrm{l}$ DNA Taq polymerase; $2.5 \mu \mathrm{l}$ PCR reaction buffer; $2,5 \mu \mathrm{l}$ Dithiotreitol $(100 \mathrm{mM}) ; 1$ $\mu \mathrm{l}$ dNTPs $(5 \mathrm{mM}) ; 1 \mu \mathrm{l}$ each primer $(1 \mathrm{mM}) ; 3,5 \mu l$ template DNA and ultrapure water up to $25 \mu \mathrm{l}$ final volumes (modified from Holmes et al. 2004).

During preliminary study, thermal cycles were as follows: denaturation step for 3 minutes at $94^{\circ} \mathrm{C}$, and followed by 35 cycles: one minute at $94^{\circ} \mathrm{C}, 2$ minutes at $40^{\circ} \mathrm{C}$ for annealing, and one minute at $72^{\circ} \mathrm{C}$ for elongation Final extension was carried out at 72 ${ }^{\circ} \mathrm{C}$ for 5 minutes (Rego et al. 2002). This protocol was modified to consist of an initial denaturation at $94^{\circ} \mathrm{C}$ for 3 minutes, followed by 45 cycles of $10 \mathrm{~s}$ at $94^{\circ} \mathrm{C}, 10 \mathrm{~s}$ at $38^{\circ} \mathrm{C}$ and $90 \mathrm{~s}$ at $72^{\circ} \mathrm{C}$, and then a final extension at $72^{\circ} \mathrm{C}$ for 10 minutes for RAPD-PCR analysis using 4 selected primers. A $20 \mu \mathrm{L}$ portion of amplicon was migrated at 100 Voltage on a 1.0\% agarose gel and visualized under UV illumination Gel Documentation.

\section{Data Analysis}

Genetic diversity level were analyzed using the following formula: averages polymorphic loci $(P)=$ number of polymorphic loci divided by total loci time hundred percent. A locus said to be as polymorphic loci if the frequency of the most common allele is less than 0.95 (Hartl \& Clark 1997). $H=\sum\left(1 \sum \chi_{i}^{2}\right) / n, \chi_{i}$ is $i_{\text {th }}$ allele frequency at $\chi$ locus within a given population; $n$ is total number of loci under study (Baozhong et al. 2006). Gene diversity (H) and it standard deviations are estimated to evaluate genetic diversity of $P$. erosa population. The calculation was performed with the help of Arlequin software (ver. 2.0; Schneider et al. 2000) following the recommendation from Nei (1987). Before the data were applied to the software, the RAPD's band patterns were changed into binary data $(0: 1 ; 0$ mean the fragments were not present and 1 mean present).

\section{RESULTS AND DISCUSSIONS}

During pre-experiment periods, we had also designed special program to amplify DNA to obtain high genetic diversity on PCR-RAPD marker analysis. Optimization of thermal cycle condition was done to obtain reproducible fingerprint. Optimization was conducted as follows: pre-denaturation for $2-3$ minutes, followed by 35 cycles: one 
minute denaturation at $94^{\circ} \mathrm{C}$, annealing for 10 - 30 seconds at $38-40{ }^{\circ} \mathrm{C}$, elongation at $72^{\circ} \mathrm{C}$ for one minute and final extension for 5 minutes at $72^{\circ} \mathrm{C}$. Finally, thermal cycle was performed as follows: pre-denaturation at $94^{\circ} \mathrm{C}$ for 3 minutes and followed by 45 cycles as follows: denaturation steps at $94^{\circ} \mathrm{C}$ for 10 seconds, annealing steps for 10 seconds at temperature of $38^{\circ} \mathrm{C}$, and extension steps for 1.5 minutes at $72^{\circ} \mathrm{C}$, further extension was performed for 10 minutes at $72{ }^{\circ} \mathrm{C}$. However, during those periods, RAPD marker could only be amplified from seven individuals out of twenty isolated individuals. Therefore, the analysis was then continued based on seven individuals of mud clam.

In the beginning of the study, we used ten arbitrary primers to amplify RAPD marker from P. erosa tissue samples. Four out of the ten arbitrary primers could amplify RAPD marker successfully. The successful primers were GEN13, GEN15, GEN23, and GEN24. However, only three out of four primers resulted to RAPD markers with clear and clean band patterns. They are GEN15, GEN23, and GEN24. GEN13 primer resulted unclear band pattern of RAPD markers. On a same reaction condition, the main bands of RAPD product using GEN15, GEN23, and GEN24 primers has shown a similar and consistent band patterns after several PCRs and electrophoresis. Therefore, GEN15, GEN23, and GEN24 primers can be further used for RAPD analysis on P. erosa tissue samoles.

A total of 23 RAPIGEN24 GEN23 and GEX24) with the size ranges from 250 to 1500 base pairs (bp). However, among seven frdividual samples, GEN15 primer only amplified RAPD markers from 5 individuzls. Using this primer, RAPD marker only appeared from individua $\bar{\equiv}$ ber 2, 3, 4, , and 7, while on individual number 1 and 5 did not (Table 1). GEN 23 and Gent primer were able to amplify RAPD markers from all analyzed individuals.

Table 1. The selected primers for genetic diversity analysis of P. erosa population from Segara Anakan Cilacap.

\begin{tabular}{lccccc}
\hline Primer & $\begin{array}{c}\text { Number of } \\
\text { Amplified } \\
\text { Band }\end{array}$ & $\begin{array}{c}\text { Number of } \\
\text { Band per } \\
\text { Individual }\end{array}$ & $\begin{array}{c}\text { Number of } \\
\text { Monomorphic } \\
\text { Band }\end{array}$ & $\begin{array}{c}\text { Number of } \\
\text { Polymorphic } \\
\text { Band }\end{array}$ & $\begin{array}{c}\text { Polymorphis } \\
\mathrm{m} \%\end{array}$ \\
\hline GEN15 & 6 & $0-4$ & 0 & 6 & 100 \\
GEN23 & 7 & $2-4$ & 0 & 7 & 100 \\
GEN24 & 10 & $3-4$ & 0 & 10 & 100 \\
Total & 23 & 0 & 23 & 100 \\
\hline
\end{tabular}

Amplification using GEN15 primer resulted to six RAPD markers with the size range of 300 to $1250 \mathrm{bp}$. GEN23 primer was able to amplify seven RAPD markers with the size between 250 and $750 \mathrm{bp}$. Whereas amplification using GEN24 primer resulted to ten RAPD markers with the size range of 350 to 1500 base pairs. The phenotype distribution of RAPD markers on Polymesoda erosa population from the Segara Anakan Cilacap are summarized on Table 2. 
Table 2. Phenotype distribution based on RAPD markers frequency on Polymesoda erosa population from the Segara Anakan, Cilacap

\begin{tabular}{lcc}
\hline Marker & Number of Phenotype for each marker & Distribution \\
\hline GEN13-1250 & 2 & 0.091 \\
GEN13-1000 & 2 & 0.091 \\
GEN13-600 & 2 & 0.091 \\
GEN13-500 & 1 & 0.045 \\
GEN13-400 & 3 & 0.136 \\
GEN13-300 & 4 & 0.182 \\
GEN23-750 & & \\
GEN23-700 & 2 & 0.091 \\
GEN23-600 & 1 & 0.045 \\
GEN23-500 & 3 & 0.136 \\
GEN23-400 & 3 & 0.136 \\
GEN23-300 & 5 & 0.227 \\
GEN23-250 & 5 & 0.227 \\
GEN24-1500 & 5 & 0.227 \\
GEN24-1300 & & \\
GEN24-1250 & 1 & 0.045 \\
GEN24-1100 & 1 & 0.045 \\
GEN24-800 & 5 & 0.227 \\
GEN24-750 & 2 & 0.091 \\
GEN24-700 & 3 & 0.136 \\
GEN24-625 & 2 & 0.091 \\
GEN24-450 & 1 & 0.045 \\
GEN24-350 & 6 & 0.273 \\
\hline
\end{tabular}

Genetic diversity analysis of all the 23 RAPD markers showed very high polymorphisms (100\%). On gene level, according to the result of genetic diversity analysis using Arlequin software, Polymesoda population from the Segara Anakan showed high genetic diversity $(1.000 \pm 0.076)$ (Table 3). High gene diversity also proved that the used RAPD markers showed high heterozygosity. Lynch and Miligan (1994) noted that at Hardy-Weinberg equilibrium gene diversity is equivalent with expected heterozygosity. Therefore, mud clams P. erosa from the Segara Anakan areas has high genetic diversity and heterozygosity.

Table 3. Analysis of standard genetic diversity using Arlequin Software

\begin{tabular}{cccccc}
\hline $\begin{array}{c}\text { No. of } \\
\text { gene } \\
\text { copies }\end{array}$ & $\begin{array}{c}\text { Number of } \\
\text { haplotypes }\end{array}$ & $\begin{array}{c}\text { Number of } \\
\text { loci }\end{array}$ & $\begin{array}{c}\text { Number of } \\
\text { usable loci }\end{array}$ & $\begin{array}{c}\text { Number of } \\
\text { polymorphic } \\
\text { sites }\end{array}$ & Gene diversity \\
\hline 7 & 7 & 23 & 23 & 23 & $1.0000 \pm 0.0764$ \\
\hline
\end{tabular}

From culture and conservation point of view, high genetic diversity, polymorphisms and heterozygosity of P. erosa population are very advantageous. It is due to genetic diversity that can be used as an indicator of adaptive potential related to environmental alteration (O'Brien 1994). Therefore, it is expected that high genetic 
diversity, polymorphisms and heterozygosity of P. erosa population from the Segara Anakan could indicate high adaptation of those population to their environment. A high genetic diversity might improve population resistance (Hughes \& Stachowicz 2004; Tarpy 2003). In contrast, loss of genetic diversity has deleterious effect on population fitness (Reed \& Frankham 2003).

Based on its high genetic diversity, at the present time, we could say that the population of P. erosa in Segara Anakan Cilacap is still in a save condition. This high heterozygosity, polymorphism, and genetic diversity might indicate normal exploitation. However, we have still to pay attention to exploitation rate of P. erosa population in the Segara Anakan Cilacap to avoid a worse effect of ove-rexploitation in the future, since this clam is exploited daily and continuously by the fisherman. Daily and continuous exploitation will lead to over-exploitation. Over-exploitation might lead to a loss of genetic diversity on those populations. This condition has a further consequence on sustainable use of those clams in the Segara Anakan Cilacap. Ledig (1992) and Hauser et al. (2002) noted that over-exploitation has caused a deep loss of genetic diversity within population. This situation has adverse effect on the sustainability of population because loss of genetic diversity has deleterious effect on population fitness (Reed \& Frankham 2003). Conversely, a low genetic diversity might lead to low potential adaptation, population resistance and low reproductive capacity (Hauser et al. 2002), whereas high genetic diversity might improve population resistance (Hughes \& Stachowicz 2004; Tarpy 2003).

\section{CONCLUSIONS}

According to our result and discussion it can be concluded that: 1) three out of four selected primers were able to amplify RAPD marker and resulted to polymorphic bands; 2) Polymesoda erosa population from the Segara Anakan Cilacap has high heterozygosity and genetic diversity; 3) the exploitation of P. erosa in Segara Anakan is still at normal rate.

\section{REFERENCES}

Aranishi F. and T. Okimoto. 2004. Genetic relationship between cultured populations of Pacific oyster revealed by RAPD analysis. Journal of Applied Genetics, 45 (4): 435-443.

Baozhong L., Y. Feng, D. Bo, and X. Jianhai. 2006. The comparison between allozyme and RAPD makers for the population genetic structure analysis of scallop Chlamys farreri. Chinese Journal of Oceanology and Limnology, 24 (3): 295-299.

Dudley R.G., Nurhayati T., Pamungkas H. and T. Nurcahyo. 2000. Segara Anakan Fisheries Management Plan. Segara Anakan Conservation and Development Project. Component B and C. Consultant's Report.

Fe'ral Jean-Pierre. 2002. How useful are the genetic markers in attempts to understand and manage marine biodiversity? Journal of Experimental Marine Biology and Ecology, 268: 121-145.

Gimin R., Mohan R., Thinh L.V. and A.D. Griffiths. 2004. The relationships of shell dimension and shell volume to live weight and soft tissue weight in the mangrove clam Polymesoda erosa (Solander, 1786) from northern Australia. NAGA, WorldFish Centre Quarterly, 27: 32-35. 
Hadie W., Pouyaud L. and L.E. Hadie. 1998. The implementation of molecular genetics on walking catfish Clarias batrachus for its sustainable culture. Jurnal Penelitian Sains dan Teknologi. Special Edition FMIPA, UNILA. p. 350-355.

Hanley R. 2000. Conservation and Development Project in Segara Anakan: Strategy for Rehabilitation of Tambaks with Mangrove Using Empang Parit Models. BECEOM French Consulting Group, Cilacap.

Hadrys H., Balick M. and B. Schierwater. 1992. Applications of random amplified polymorphic DNA (RAPD) in molecular ecology. Molecular Ecology, 1: 5563.

Hartl D.L. and A.G. Clark. 1997. Principles of Population Genetics. Third edition. Sunderland, Massachusetts, USA: Sinnauer Associates Inc. Publisher.

Hauser L., Adcock G.J., Smith P.J., Bernal Ramirez J.H. and G.R. Carvalho. 2002. Loss of micro satellite diversity and low effective population size in an overexploited population of New Zealand snapper (Pagrus auratus). PNAS 99, (18): 11742-11747.

Hirschfeld B.M., Dhar A.K., Rask K. and A. Alcivar-Warren. 1999. Genetic diversity in the eastern oyster (Crassostrea virginica) from Massachusetts using the RAPD technique. Journal of Shellfish Research, 18: 121-125.

Holmes S. P., Dekker R. and I.D. Williams. 2004. Population dynamics and genetic differentiation in the bivalve mollusk Abra tenuis: aplanic dispersal. Marine Ecology Progress Series, 268: 131-140.

Huang B.X., Peakall R. and P.J. Hanna. 2000. Analysis of genetic structure of black lip abalone (Haliotis rubra) populations using RAPD, mini satellite and micro satellite markers. Marine Biology, 136: 207-216.

Hughes A.R. and J.J. Stachowicz. 2004. Genetic diversity enhances the resistance of a sea grass ecosystem to disturbance. PNAS, 101 (24): 8998-9002.

Indriani F.C., Soetopo L., Sudjindro and A.N. Sugiharo. 2002. Genetic diversity of Hibiscus cannabicus L. and its relative based on isozymes analysis. Biosains, 2 (1): 29-39.

Ingole B.S., Naik S., Furtado R., Ansari Z.A. and A. Chatterji. 2002. Population characteristics of the mangrove clam Polymesoda (gelonia) erosa (Solander, 1786) in the Chorao mangrove, Goa. Extended SummariesNCCAR, 6-7 April 2002, Goa.

Kempton R.A. 1979. The structure of species abundance and measurement of diversity. Biometrics. 35: 307321.

Klinbunga S., Ampayup P., Tassanakajon A., Jarayabhand P. and W. Yoosukh. 2000. Development of speciesspecific markers of the tropical oyster (Crassostrea belcheri) in Thailand. Marine Biotechnology, 2: 47604484.

Klinbunga S., Ampayup P., Tassanakajon A., Jarayabhand P. and W. Yoosukh. 2001. Genetic diversity and molecular markers of cupped oysters (genera Crassostrea, Caccostrea, and Striostrea) in Thailand revealed by randomly amplified polymorphic DNA analysis. Marine Biotechnology, 3: 133-144.

Lambshead P.J.D., Platt H.M. and K.M. Shaw. 1983. The detection of differences among assemblages of marine benthic species based on assessment of dominance and diversity. Journal of Natural History, 17: 859874.

Lande R. and G.F. Barrowclough. 1987. Effective size, genetic variation, and their use in population management. In : Soule, M., and M. Gilpin (Eds): Viable population for conservation. Sinauer and Associates, Sunderland. p. 87-123.

Ledig F.T. 1992. Human impact on genetic diversity in forest ecosystems. Oikos, 63: 87-108.

Lynch M. and B.G. Milligan. Analysis of population genetic structure with RAPD markers. Molecular Ecology, 3: 91-99.

Marin S.A., Haye P.A., Marchant S. and F.M. Winkler. 2007. Molecular marker used to analyze species-specific status in marine abalone with ambiguous morphology. Journal of Shellfish Research, 26 (3): 833-837.

Meehan B. 1982. Shell Bed to Shell Midden. Australian Institute of Aboriginal Studies, Canberra.

Morton B. 1976. The biology and functional morphology of the Southeast Asian mangrove bivalve, Polymesoda (Gelonia) erosa (Solander 1786) (Bivalvia: Corbiculidae). Canadian Journal of Zoology, 54: 483-500.

Nei M. 1987. Molecular Evolutionary Genetics. New York: Columbia University Press. 
O'Brien S. J. 1994. A role for molecular genetics in biological conservation. Proceedings National Academy of Sciences, USA. 21: 5748-5755.

Patwary M.U., Kenchington E.L., Bird C.J. and E. Zouros. 1994. The use of random amplified polymorphic DNA markers in genetic studies of the sea scallop, Placopecten magellanicus (Gmelin 1791). Journal of Shellfish Research, 13: 547-553.

Penner G.A., Bush A., Wise R., Kim W., Domier L., Kasha K., Laroche A., Scoles G., Molnar S.J. and G. Fedak. 1993. Reproducibility of random amplified polymorphic DNA (RAPD) analysis among laboratories. Genome Research, 2:341-345.

Purwanto E., E. Sukaya, Setianto dan H. Santoso. 2002. Identification based on isozymes marker on Citrus maxima Merr. in Blora Central Java. Bio SMART . 4 (2): 44-47.

Reed D.H. and R. Frankham. 2003. Correlation between fitness and genetic diversity. Conservation Biology, 17 (1): 230-237.

Rego I., Martianez A.S., Lez-Tizoa N. A.G, Vieites J., Leira F. and J. Meandez. 2002. PCR Technique for Identification of Mussel Species. Journal of Agricultural Food Chemistry, 50: 1780-1784.

Sastranegara M.H. 2004. The Impact of Forest Used on the Intertidal Crab Community in Managed Mangroves of Cilacap, Central Java, Indonesia. Cuvillier Verlag, Gotingen.

Savolainen O. 1994. Genetics Variations and Fitness: Conservation Lesson for Pines. In: Loeschcke V., Tomiuk J. and S.K. Jain (Eds): Conservation Genetics. Basel, Boston, Berlin. 27-36.

Schneider, S., D. Roessli, and L. Excoffier. 2000. Arlequin, version 2.000. University of Geneva, Geneva.

Star B., Apte S. and J.P.A. Gardner. 2003. Genetic structuring among populations of the green shell mussel Perna canaliculus revealed by analysis of randomly amplified polymorphic DNA. Marine Ecology Progress Series, 249: 171-182.

Stepien C.A., Taylor C.D. and K.A. Dabrowska. 2002. Genetic variability and phylogeographical patterns of a nonindigenous species invasion: a comparison of exotic vs. native zebra and quagga mussel populations. Journal of Evolutionary Biology, 15: 314-328.

Surjadi H. 2002. Draft Dokumen IBSAP Bagian 3/8, Tinjauan : Keanekaragaman Hayati sebagai Aset Produktif Pembangunan Berkelanjutan. www. polarhome.com (email : nasional-a@polarhome). Access 18 March 2006.

Tarpy D.R. 2003. Genetic diversity within honeybee colonies prevents severe infections and promotes colony growth. Proceedings of the Royal Society, London. B 270: 99-103.

Ward R.D. and P.M. Grewe. 1994. Appraisal of molecular genetics techniques in fisheries. Reviews in Fish Biology and Fisheries, 4:300-325.

Walsh J., and M. McClelland. 1990. Fingerprinting genomes using PCR with arbitrary primers. Nucleic Acids Research, 18: 7213-7218.

Williams J.G.K., Kubelik A.R., Livak K.J., Rafalski J.A. and S.V. Tingey. 1990. DNA polymorphisms amplified by arbitrary primers are useful as genetic markers. Nucleic Acids Research, 18: 6513-6535. 